\title{
Cloacal Temperature Responses and Some Performance Indices in Black Harco Pullets Administered with Betamint during the Hot-Dry Season Joseph Olusegun Ayo ${ }^{1 *}$, Samaila Danbirini ${ }^{2}$, Ifeanyichukwu Chukwuemeka Egbuniwe ${ }^{1}$ and Victor Olusegun Sinkalu ${ }^{1}$ \\ ${ }^{1}$ Department of Physiology, Faculty of Veterinary Medicine, Ahmadu Bello University, Nigeria \\ ${ }^{2}$ Veterinary Teaching Hospital, Faculty of Veterinary Medicine, Ahmadu Bello University, Nigeria
}

\begin{abstract}
The experiment was performed with the aim of determining fluctuations in cloacal temperature (CT) of Black Harco pullets, and effects of betamint $\AA$ on the fluctuations and some performance indicesof the pullets during the hot-dry season. Twenty-five experimental pullets were each administered with betamint orally at a dose of $1 \mathrm{ml} / \mathrm{kg}$ daily, while 25 other control pullets were given only water for 21 days. The dry-bulb temperature, relative humidity inside the pen and CT of each pullet were recorded every two hours (from 06:00 h to 18:00 h) on days 7, 14 and 21 . CT values in experimental and control pullets $\left(41.63 \pm 0.10^{\circ} \mathrm{C}\right.$ and $41.64 \pm 0.13^{\circ} \mathrm{C}$, respectively) did not differ, but betamint reduced $(\mathrm{P}<0.05) \mathrm{CT}$ values in the pullets from 12:00 $\mathrm{h}$ and 14:00 $\mathrm{h}$. Water consumption in experimental $(4.26 \%)$ pullets was lower than that of the control $(23.63 \%)$ pullets. An increase in live weight gain (15\%) and feed consumption $(45.91 \%)$ was obtained in experimental pullets over that of the control pullets $(P<0.01)$. In conclusion, betamint administration alleviated the risk of adverse effects of heat stress and improved live weight gain in pullets.
\end{abstract}

Keywords: Heat stress; Productivity; Thermal microenvironment

\section{Introduction}

Heat stress is a major challenge to poultry framers in tropical and sub-tropical countries, and is anticipated to spread widely owing to increasing global climate warming [1]. High ambient temperature (AT) acting concurrently with high relative humidity (RH) have been shown to cause heat stress $[2,3]$, which has adverse effects on the development of immunity [4], resistance to diseases, growth rate and production of birds $[5,6]$. Heat stress causes reduction of feed consumption [7], high mortality [8], decreased growth rate and meat yield $[9,10]$, and breast protein content of birds. Mujahid et al. [11] showed that high production of reactive oxygen species (ROS) occurs in broilers exposed to acute heat stress at $34^{\circ} \mathrm{C}$ for 18 hours. These ROS, generated mostly during mitochondrial adenosine triphosphate production, exert direct and negative effects on cell growth and development [12-14]. Heat stress also has negative impact on the physiological parameters and reproductive performance of domestic chickens, and measures aimed at ameliorating its negative effects may increase livestock production $[15,16]$. The administration of the antioxidant, ascorbic acid (AA) to birds has been shown to reduce the negative responses of the body to heat stress $[17,18]$ by increased thyroid activity, as measured by ${ }^{125} \mathrm{I}$ uptake, increased oxygen intake and maintenance of metabolic rate [19]. Besides AA, an important agent that may be used to alleviate adverse effects of heat stress is betamint. It is an oral solution produced by Invesa International, Spain, which comprises the following nutrients: betaine $(250 \mathrm{~g})$, vitamin C (90 g), potassium chloride ( $2 \mathrm{~g})$, magnesium chloride hexahydrated $(40 \mathrm{~g})$, calcium chloride dihydrated $(40 \mathrm{~g})$ and sodium chloride (20 g). It is a mentholated oral solution for use in drinking water which relieves the symptoms, including dehydration associated with heat stress in poultry. Betaine has been shown to improve antioxidant defence and meat quality in broilers. It decreases lipid peroxidation in breast muscles, but increases activities of glutathione peroxidase, catalase and superoxide oxidase in broiler chickens [20]. It has been shown under temperate conditions that betamint reduces mortality and productivity, caused by heat stress, due to its rehydrating, anti-stress and refreshing properties [21]. However, the detail mechanism underlying the action of betamint has not been elucidated, especially under tropical conditions. It has been established that heat stress in livestock is evaluated by measuring the body temperature [22-25], which is often assessed by measuring the cloacal temperature (CT) in birds. The CT is also an important index of thermal balance in livestock, including poultry $[22,23,26]$. In Nigeria, the Black Harco breed of chicken is popularly raised for its ability to produce good-quality eggs. There is paucity of information on the modulatory role of betamint on the CT fluctuations of pullets during the hot-dry season.

The aim of the experiment was to evaluate CT responses and some indices of performance of Black Harco pullets, administered with betamint during the hot-dry season in the Northern Guinea Savannah zone of Nigeria.

\section{Materials and Methods}

\section{Experimental site and climatic conditions}

The birds were kept in a farm in Zaria $\left(11^{\circ} 10^{\prime} \mathrm{N} ; 07^{\circ} 38^{\prime} \mathrm{E}\right)$, located in the Northern Guinea Savannah zone of Nigeria. The experiment was carried out during the hot-dry season, established to occur from March to May [26-28], and it lasted three weeks, from April 5 to April 26.

\section{Experimental animals}

Fifty pullets aged 7 weeks, belonging to Black Harco breed and

*Corresponding author: Joseph Olusegun Ayo, Department of Physiology, Faculty of Veterinary Medicine, Ahmadu Bello University, Nigeria, Tel: +2348036011204, E-mail: ayojo94@yahoo.com

Received February 18, 2014; Accepted April 02, 2014; Published April 04, 2014 Citation: Ayo JO, Danbirini S, Egbuniwe IC, Sinkalu VO (2014) Cloacal Temperature Responses and Some Performance Indices in Black Harco Pullets Administered with Betamint during the Hot-Dry Season. J Veterinar Sci Technol 5: 166. doi:10.4172/2157-7579.1000166

Copyright: () 2014 Ayo JO, et al. This is an open-access article distributed under the terms of the Creative Commons Attribution License, which permits unrestricted use, distribution, and reproduction in any medium, provided the original author and source are credited. 
weighing $0.25 \mathrm{~kg}-0.43 \mathrm{~kg}$ were used for the experiment. They were selected randomly from a flock of 400 birds. All the pullets were given access to standard chicks' mash (Vital Feeds, Grand Cereals, Jos, Nigeria) ad libitum; and housed in pens with the rest of the flock members, but were separated with wooden boards. The pullets were, therefore, subjected to the same ambient temperature and relative humidity. The pullets were routinely vaccinated against Marek's disease (at day zero of age subcutaneously), infectious bursal disease (at days 10 and 24 orally in drinking water) and Newcastle disease [at days 3 (intraocular), 21 (orally in drinking water with Lasota strain) and 47 (intramuscularly) with Komarov strain, respectively]. They were divided into groups I and II, each comprising 25 birds. Group I pullets served as experimental birds, while pullets in group II were used as control birds. Each bird was identified by directly writing numbers on the featherless area under the wings using marker. Throughout the experimental period, betamint was administered to pullets in the experimental group using gavage, while pullets in the control group were given only water.

\section{Experimental measurements}

Live weights of all the experimental and control pullets were taken on the day of commencement (Day 1) and the last day (Day 21) of the experiment, using a top loading scale [29] and a weighing scale (Hana Company, Shanghai, China). The birds were identified by numbers written with indelible markers on the featherless region under their wings. The CT, as an indication of the body temperature, of each bird was recorded using a clinical thermometer (Hartmann's Company Plc., U.K.), inserted $2 \mathrm{~cm}$ into the cloaca every two hours from 06:00 h to $18: 00 \mathrm{~h}$ on days 7,14 , and 21 . The dry-bulb temperature (DBT) and wet-bulb temperature measurements were also taken concurrently with the CT using a dry-bulb and thermometer (Branman, England), respectively, and relative humidity was obtained using Omson's hygrometric table (Narindra Scientific Industries, Haryana, India). The temperature-humidity Index (THI) was calculated using the equation of Zulovich and DeShazer, [30].

$$
\mathrm{THI}_{\text {Layers }}=0.6 \mathrm{~T}_{\mathrm{db}}+0.4 \mathrm{~T}_{\mathrm{wb}}
$$

(Where $\mathrm{THI}_{\text {Layers }}=$ Temperature-humidity index for layers, $\mathrm{T}_{\mathrm{db}}=$ Dry-bulb temperature, $\mathrm{T}_{\mathrm{wb}}=$ Wet-bulb temperature).

The experimental pullets were individually administered with betamint (Invesa, Bacerlona, Spain) orally using a gavage at the dose of $1 \mathrm{ml} / \mathrm{kg}$. The control pullets were individually given equivalent water orally, but without any medication. Both the experimental and control pullets were given access to feed ad libitum. The procedures were carried out daily throughout the experimental period. The quantities of feeds and water consumed were measured daily by obtaining the differences between the amount given the previous day and the amount left in the feeders and drinkers, respectively.

\section{Statistical analysis}

The data obtained are expressed as mean \pm standard error of the mean $($ Mean \pm SEM). The values were subjected to Student's $t$-test and Pearson's correlation analysis, as well as analysis of variance (ANOVA), which was used to compare the values obtained every two hours. Values of $\mathrm{P}<0.05$ were considered significant [31].

\section{Results}

The DBT was lowest at $06: 00 \mathrm{~h}$, while the highest was recorded at $16: 00 \mathrm{~h}$ with the values of $24.33 \pm 0.72^{\circ} \mathrm{C}$ and $38.33 \pm 1.19^{\circ} \mathrm{C}$, respectively. The experimental period was characterized by very low $\mathrm{RH}$, with lowest and highest mean values fluctuating between $27.33 \pm 4.46 \%$ and $65.67 \pm 3.29 \%$, respectively, and the values were recorded at 06:00 $\mathrm{h}$ and 14:00 $\mathrm{h}$, respectively. The DBT values in all the experimental days were not significantly different and they fluctuated between $23-41^{\circ} \mathrm{C}$. The THI value was highest $(45.59 \pm 0.85)$ at $16: 00$ $\mathrm{h}$ and the highest DBT $(38: 33 \pm 1.19)$ was also recorded at 16:00 $\mathrm{h}$ (Table 1). There was a marked difference in all the daily RH values, fluctuating from $19-45 \%$. The mean values of daily THI values $(44.39 \pm 0.88,41.95 \pm 1.31,43.99 \pm 0.42$ and $43.44 \pm 0.76)$ were not significantly different from one another, and the values ranged from 36.5 to 47.25 (Table 2).

There was no significant difference $(\mathrm{P}>0.05)$ between the overall mean values of CT obtained in the experimental and control pullets on each day of the recordings. However in both experimental and control pullets, there was a significant $(\mathrm{P}<0.05)$ difference between the CT values recorded on days 7 , when compared to that obtained on day 21 of betamint administration (Table 3 ). The overall mean values

\begin{tabular}{|c|c|c|c|c|}
\hline $\begin{array}{l}\text { Hour of Day } \\
\text { (h) }\end{array}$ & $\begin{array}{c}\text { Dry-bulb } \\
\text { temperature } \\
\text { (oC) }\end{array}$ & $\begin{array}{l}\text { Wet-bulb } \\
\text { temperature } \\
\text { (oC) }\end{array}$ & $\begin{array}{c}\text { Relative } \\
\text { Humidity (\%) }\end{array}$ & $\begin{array}{l}\text { Temperature- } \\
\text { humidity Index }\end{array}$ \\
\hline \multirow[t]{2}{*}{ 6:00 } & $24.33 \pm 0.72$ & $20.00 \pm 2.00$ & $65.67 \pm 3.29$ & $22.60 \pm 1.25$ \\
\hline & $(23.00-26.00)$ & $(16.00-22.00)$ & $(45.00-83.00)$ & $(20.20-24.40)$ \\
\hline \multirow[t]{2}{*}{ 8:00 } & $27: 00 \pm 0.94$ & $20.67 \pm 1.86$ & $55.33 \pm 4.65$ & $24.47 \pm 1.09$ \\
\hline & $(25.00-29.00)$ & $(17.00-23.00)$ & $(32.00-76.00)$ & $(23.00-26.60)$ \\
\hline \multirow[t]{2}{*}{ 10:00 } & $30.67 \pm 1.36$ & $22.00 \pm 1.53$ & $47.00 \pm 5.74$ & $27.20 \pm 0.42$ \\
\hline & $(29.00-34.00)$ & $(19.00-24.00)$ & $(19.00-64.00)$ & $(26.60-28.00)$ \\
\hline \multirow[t]{2}{*}{$12: 00$} & $36.33 \pm 1.52$ & $23.67 \pm 0.33$ & $32.33 \pm 4.02$ & $31.27 \pm 0.98$ \\
\hline & $(34.00-40.00)$ & $(23.00-24.00)$ & $(20.00-41.00)$ & $(30.00-33.20)$ \\
\hline \multirow[t]{2}{*}{$14: 00$} & $38.00 \pm 0.94$ & $23.67 \pm 0.67$ & $27.33 \pm 4.46$ & $32.27 \pm 0.48$ \\
\hline & $(36.00-40.00)$ & $(23.00-25.00)$ & $(20.00-38.00)$ & $(31.60-33.80)$ \\
\hline \multirow[t]{2}{*}{$16: 00$} & $38.33 \pm 1.19$ & $24.00 \pm 1.00$ & $28.67 \pm 1.00$ & $32.60 \pm 0.60$ \\
\hline & $(36.00-40.00)$ & $(23.00-26.00)$ & $(19.00-43.00)$ & $(32.00-33.80)$ \\
\hline \multirow[t]{2}{*}{ 18:00 } & $36.33 \pm 0.98$ & $23.00 \pm 0.58$ & $29.67 \pm 0.38$ & $31.00 \pm 0.50$ \\
\hline & $(34.00-38.00)$ & $(22.00-24.00)$ & $(20.00-41.00)$ & $(30.00-31.60)$ \\
\hline \multirow[t]{2}{*}{ Mean \pm SEM } & $33.00 \pm 1.09$ & $22.43 \pm 0.60$ & $40.95 \pm 4.37$ & $28.77 \pm 1.52$ \\
\hline & $(23.00-41.00)$ & $(16.00-26.00)$ & $(19.00-83.00)$ & $(22.60-32.60)$ \\
\hline
\end{tabular}

Values with parenthesis are minimum - maximum

Table 1: Hourly Fluctuations in Thermal Microenvironment Parameters during the Hot-dry Season.

\begin{tabular}{|l|c|c|c|c|}
\hline Day & $\begin{array}{c}\text { Dry-bulb } \\
\text { temperature }\left({ }^{\circ} \mathrm{C}\right)\end{array}$ & $\begin{array}{c}\text { Wet-bulb } \\
\text { temperature }\left({ }^{\circ} \mathrm{C}\right)\end{array}$ & $\begin{array}{c}\text { Relative } \\
\text { Humidity }(\%)\end{array}$ & $\begin{array}{c}\text { Temperature- } \\
\text { humidity Index }\end{array}$ \\
\hline 7 & $31.4 \pm 1.93$ & $23.86 \pm 0.55$ & $55.14 \pm 2.81$ & $28.23 \pm 1.37$ \\
\hline & $(24.00-36.00)$ & $(22.00-26.00)$ & $(38.00-83.00)$ & $(23.20-32.00)$ \\
\hline 14 & $34.71 \pm 2.69$ & $20.43 \pm 1.15$ & $25.00 \pm 1.98$ & $29.00 \pm 2.07$ \\
\hline & $(23.00-41.00)$ & $(16.00-23.00)$ & $(19.00-45.00)$ & $(20.20-33.80)$ \\
\hline 21 & $33.00 \pm 2.17$ & $23.00 \pm 0.22$ & $42.71 \pm 2.76$ & $29.09 \pm 1.19$ \\
\hline Mean \pm SEM & $(26.00-38.33)$ & $(22.00-24.00)$ & $(24.00-69.00)$ & $(24.40-32.00)$ \\
\hline & $33.00 \pm 2.17$ & $22.43 \pm 1.03$ & $40.95 \pm 2.52$ & $28.77 \pm 0.27$ \\
\hline & $(24.33-38.33)$ & $(20.43-23.86)$ & $(27.00-65.67)$ & $(28.23-29.09)$ \\
\hline
\end{tabular}

Values in parenthesis are minimum - maximum

Table 2: Daily Variations in Thermal Microenviroment Parameters during the Experimental Period of the Hot-dry Season. 
Citation: Ayo JO, Danbirini S, Egbuniwe IC, Sinkalu VO (2014) Cloacal Temperature Responses and Some Performance Indices in Black Harco Pullets Administered with Betamint during the Hot-Dry Season. J Veterinar Sci Technol 5: 166. doi:10.4172/2157-7579.1000166

Page 3 of 8

\begin{tabular}{|l|c|c|c|c|c|c|c|c|c|}
\hline & \multicolumn{2}{|c|}{ Mean Cloacal Temperature $\left({ }^{\circ} \mathrm{C}\right)$} & \multicolumn{2}{|c|}{ Feed Consumption $(\mathrm{kg})$} & \multicolumn{2}{|c|}{ Water Intake $(\mathrm{L})$} \\
\hline Day & Experimental & Control & Experimental & Control & Experimental & Control & Experimental & Control \\
\hline 7 & $41.56 \pm 0.11^{\mathrm{a}}$ & $41.53 \pm 0.12$ & $0.95 \pm 0.03$ & $1.8 \pm 0.06$ & $5.4 \pm 0.03$ & $3.64 \pm 0.02$ & $0.36 \pm 0.01$ & $0.34 \pm 0.01$ \\
\hline 14 & $41.63 \pm 0.11$ & $41.63 \pm 0.13$ & $1.65 \pm 0.05$ & $1.05 \pm 0.02$ & $5.5 \pm 0.02$ & $5.53 \pm 0.07$ & Not Recorded & Not Recorded \\
\hline 21 & $41.70 \pm 0.09^{\mathrm{b}}$ & $41.77 \pm 0.13$ & $1.65 \pm 0.18$ & $2.3 \pm 0.02$ & $5.63 \pm 0.02$ & $4.5 \pm 0.02$ & $0.71 \pm 0.01$ & $0.62 \pm 0.02$ \\
\hline Mean \pm SEM & $41.63 \pm 0.10$ & $41.64 \pm 0.13$ & $1.42 \pm 0.09$ & $1.72 \pm 0.03$ & $5.51 \pm 0.02$ & $4.56 \pm 0.04$ & $0.54 \pm 0.01$ & $0.48 \pm 0.02$ \\
\hline $\begin{array}{l}\text { Percentage (\%) difference between } \\
\text { Days 7 and 21 }\end{array}$ & 0.34 & 0.58 & 73.68 & 27.77 & 4.26 & 23.63 & 97.22 \\
\hline
\end{tabular}

Table 3: Effect of Betamint ${ }^{\circledR}$ Supplementation on Cloacal Temperature, Feed Consumption, Water Intake and Weight Gain in Pullets $(n=25)$ during the Hot-dry Season.

\begin{tabular}{|c|c|c|c|c|c|c|c|c|}
\hline \multirow[b]{2}{*}{ Hour of Day } & \multicolumn{2}{|c|}{ Mean \pm SEM } & \multicolumn{2}{|c|}{ Maximum } & \multicolumn{2}{|c|}{ Minimum } & \multicolumn{2}{|c|}{ Range } \\
\hline & Experimental & Control & Experimental & Control & Experimental & Control & Experimental & Control \\
\hline 06:00 & $41.34 \pm 0.07$ & $41.25 \pm 0.08$ & 42.5 & 42.3 & 40.5 & 40 & 2 & 2.3 \\
\hline 08:00 & $41.41 \pm 0.06$ & $41.28 \pm 0.07$ & 42.4 & 41.9 & 40.8 & 40.6 & 1.6 & 1.3 \\
\hline $10: 00$ & $41.43 \pm 0.06$ & $41.44 \pm 0.06$ & 42.2 & 42.2 & 40.6 & 40.6 & 1.6 & 1.6 \\
\hline $12: 00$ & $41.55 \pm 0.06$ & $41.68 \pm 0.06$ & 42.6 & 42.3 & 40.5 & 41 & 2.1 & 1.3 \\
\hline $14: 00$ & $41.78 \pm 0.05$ & $41.99 \pm 0.05$ & 42.8 & 42.8 & 41.2 & 41.6 & 1.6 & 1.2 \\
\hline $16: 00$ & $41.95 \pm 0.05$ & $42.04 \pm 0.06$ & 42.7 & 42.8 & 41.2 & 41.4 & 1.5 & 1.4 \\
\hline $18: 00$ & $41.97 \pm 0.05$ & $41.82 \pm 0.06$ & 42.5 & 42.7 & 41.3 & 41.1 & 1.2 & 1.6 \\
\hline Mean \pm SEM & $41.63 \pm 0.06$ & $41.64 \pm 0.06$ & $42.53 \pm 0.07$ & $42.43 \pm 0.13$ & $40.87 \pm 0.13$ & $40.90 \pm 0.21$ & $1.66 \pm 0.12$ & $1.53 \pm 0.14$ \\
\hline
\end{tabular}

Table 4: Effect of Betamint ${ }^{\circledR}$ Administration on Diurnal Fluctuations in Cloacal Temperature $\left({ }^{\circ} \mathrm{C}\right)$ of Pullets $(n=25)$ during the Hot-dry Season.

Correlation Coefficients

Dry-Bulb Temperature and Feed Consumption Experimental Pullets $(n=25)$

\begin{tabular}{|c|c|}
\hline \multicolumn{2}{|c|}{ Correlation Coefficients } \\
\hline Experimental Pullets $(n=25)$ & Control Pullets $(n=25)$ \\
\hline $0.899^{* * *}$ & $-0.539^{*}$ \\
\hline $0.495^{\star}$ & $0.971^{* \star *}$ \\
\hline$-0.241^{\mathrm{NS}}$ & $-0.147^{\mathrm{NS}}$ \\
\hline$-0.694^{* *}$ & $0.795^{\star *}$ \\
\hline$-0.167^{\mathrm{NS}}$ & $-0.994^{\star \star *}$ \\
\hline$-0.130^{N S}$ & $-0.142^{\mathrm{NS}}$ \\
\hline $0.422^{\mathrm{NS}}$ & $0.209^{\mathrm{NS}}$ \\
\hline$-0.034^{\mathrm{NS}}$ & $0.269^{N S}$ \\
\hline $0.866^{* * *}$ & $0.483^{*}$ \\
\hline$-0.067^{\mathrm{NS}}$ & $0.253^{\mathrm{NS}}$ \\
\hline
\end{tabular}

Dry-Bulb Temperature and Water Intake

Relative Humidity and Cloacal Temperature

Relative Humidity and Feed Consumption

Relative Humidity and Water Intake

Temperature-humidity Index and Feed Consumption

Temperature-humidity Index and Water Intake

Temperature-humidity Index and Cloacal Temperature

Cloacal Temperature and Feed Consumption

Cloacal Temperature and Water Intake

${ }^{*}=$ Significant $(P<0.05)$ correlation; ${ }^{* *}=$ Highly significant $(P<0.01)$ correlation; ${ }^{* *}=$ Very highly significant $(P<0.001)$ correlation; NS $=$ Non-significant correlation

Table 5: Relationships between Thermal Environmental Parameters and Cloacal Temperature, Feed Consumption and Water Intake in Experimental and Control Pullets during the Hot-dry Season.

Correlated Parameters

Dry-bulb Temperature and Cloacal Temperature

Hour of Day and Cloacal Temperature

Hour of Day and Maximum Cloacal Temperature

Hour of Day and Minimum Cloacal Temperature

Hour of Day and Range Cloacal Temperature

Maximum and Minimum Cloacal Temperature

Maximum and Range Cloacal Temperature

Minimum and Range Cloacal Temperature

\begin{tabular}{|c|c|c|}
\hline & \multicolumn{2}{|c|}{ Correlation Coefficients } \\
\hline & Experimental Pullets $(n=25)$ & Control $(n=25)$ \\
\hline ure & $0.559^{*}$ & $0.477^{*}$ \\
\hline & $-0.796^{*}$ & $0.850^{*}$ \\
\hline & $0.832^{* * *}$ & $0.806^{* * *}$ \\
\hline & $0.946^{* *}$ & $0.887^{* * *}$ \\
\hline & $-0.902^{* * *}$ & $-0.590^{*}$ \\
\hline & $0.951^{* * *}$ & $0.897^{* * *}$ \\
\hline
\end{tabular}

${ }^{*}=$ Significant $(P<0.05)$ correlation; ${ }^{* *}=$ Highly significant $(P<0.01)$ correlation; ${ }^{* *}=$ Very highly significant $(P<0.001)$ correlation; NS $=$ Non-significant correlation Table 6: Relationships between Hour of Day and Parameters of Cloacal Temperature in Experimental and Control Pullets during the Study Period.

of maximum and minimum CT were not significantly different in experimental and control pullets on each day of the recordings (Table 4). Feed consumption rose significantly $(\mathrm{P}<0.05)$ from $0.95 \pm 0.3 \mathrm{~kg}$ on day 7 to $1.65 \pm 0.2 \mathrm{~kg}$ per bird on day 21 of the administration in experimental pullets, with an increase of $73.68 \%$. During the same period, feed consumption also increased $(\mathrm{P}<0.05)$ in control pullets from $1.8 \pm 0.3 \mathrm{~kg}$ to $2.30 \pm 0.3 \mathrm{~kg}$ per bird, giving a percentage rise of $27.77 \%$ (Table 3 ). The live weight gain rose from $0.36 \pm 0.01 \mathrm{~kg}$ on day 7 of the experiment to $0.71 \pm 0.01 \mathrm{~kg}(\mathrm{P}<0.01)$ on day $21 \mathrm{in}$ experimental pullets. This increase in live weight gain constituted a rise of $97.22 \%$ over the pre-treatment value. In the control pullets, the weight gain rose from $0.34 \pm 0.01 \mathrm{~kg}$ on day 7 of betamint administration to $0.62 \pm 0.02 \mathrm{~kg}$ on day 21 in control pullets, giving a percentage rise of $82.35 \%$. Thus, there was an increase of about $15 \%$ of live weight gain in experimental pullets over that of control pullets (Table 3). Water intake in experimental and control pullets did not differ significantly $(\mathrm{P}<0.05)$ during the study period. However, the increase on day $21(5.63 \pm 0.2 \mathrm{~L})$ when compared to that of day $7(5.40$ 

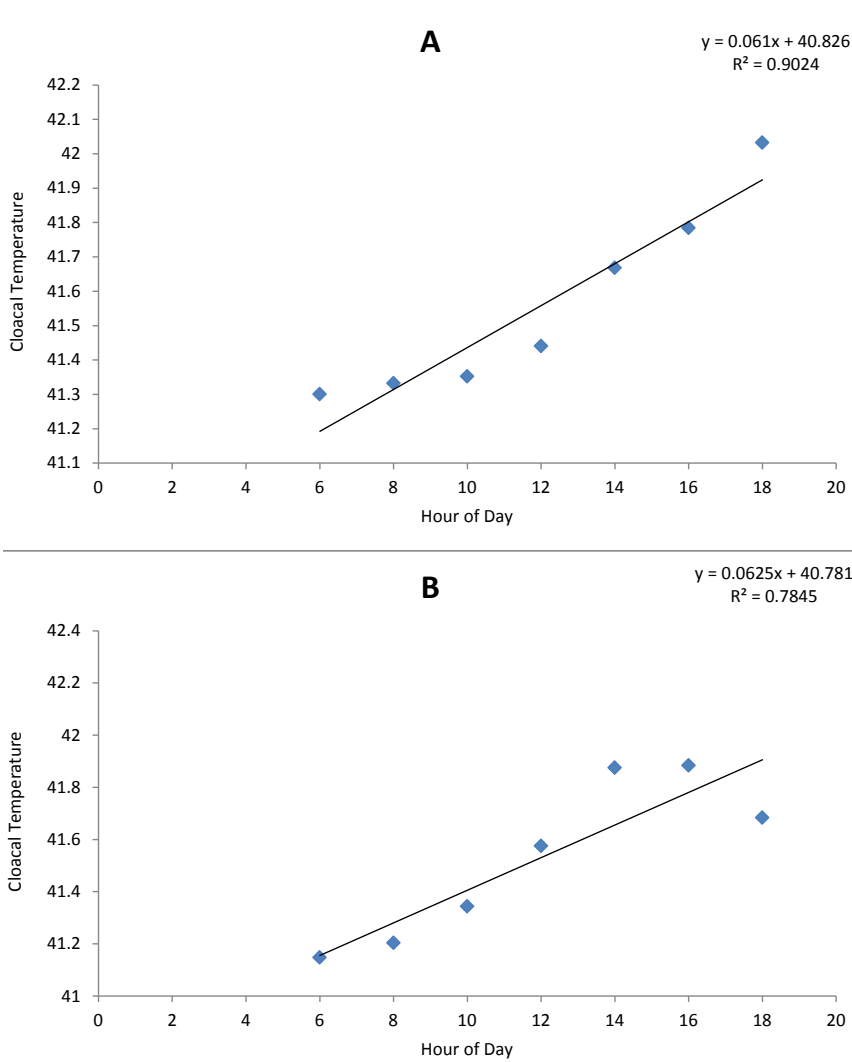

$A=$ Experimental Pullets; $B=$ Control Pullets

Figure 1: Relationship between Cloacal Temperature $\left({ }^{\circ} \mathrm{C}\right)$ and Hour of Day $(\mathrm{h})$ in Experimental (A) and Control (B) Pullets during the Hot-dry Season.

$\pm 0.4 \mathrm{~L}$ ) was $4.5 \%$ in experimental pullets, while that of the control pullets increased from $3.64 \pm 0.3 \mathrm{~L}$ on day 7 to $4.50 \pm 0.1 \mathrm{~L}$ on day 21 of the study period, giving an increase of $23.63 \%$ (Table 3 ). There were significant relationships between the hour of the day and CT $(-0.796 ; \mathrm{P}<0.05)$ in the experimental pullets (Table 6; Figures $1-3$ ). An exception was the relationship between the range value of the CT and the hour of the day, which was more negative in experimental pullets $(\mathrm{r}=-0.902 ; \mathrm{P}<0.001)$ than control pullets $(\mathrm{r}=-0.590 ; \mathrm{P}<$ 0.05) (Table 6).

There were significant correlations between the DBT and CT values in both the experimental and control pullets (Figure 4). The relationship between the DBT and feed consumption (Figure 5) was significant and positive in experimental pullets $(\mathrm{r}=0.899$; $\mathrm{P}$ $<0.01)$, but negative in control pullets $(\mathrm{r}=-0.539 ; \mathrm{P}<0.05)$. The relationship between water intake and DBT (Figure 6) was very highly significant in the control pullets $(\mathrm{r}=0.971 ; \mathrm{P}<0.01)$, but significant in experimental pullets $(\mathrm{r}=0.495 ; \mathrm{P}<0.05)$. The $\mathrm{RH}$ was negatively and insignificantly correlated with the $\mathrm{CT}$ in both experimental and control groups (Figure 7). As the RH rose, water intake in the pullets decreased, especially in the control pullets $(r=-0.994 ; \mathrm{P}<0.01)$. Feed consumption also decreased as RH rose significantly $(\mathrm{r}=-0.694 ; \mathrm{P}<$ 0.01 ) in experimental pullets. However, this relationship was positive and significant in control pullets $(\mathrm{r}=0.795 ; \mathrm{P}<0.01)$. The relationship between CT and feed consumption was positive in the experimental group, but negative in control group (Figure 8). The relationship between $\mathrm{CT}$ and water intake was negative in the experimental pullets, whereas positive in the control group, but not significant (Table 5).

\section{Discussion}

The results of the present study show that betamint administration in experimental pullets induced an increase in live weight gain of about $15 \%$ over that of the control pullets. This finding agreed with that obtained by Anonymous [21], who recorded 14\% increase, in live weight gain following betamint administration in broilers. On the overall, the percentage increase in feed consumption rate obtained in experimental pullets in the present study was $3 \%$, and the value was lower than that of $4.4 \%$ obtained by Hassan et al. [32] following treatment of growing chicks with betaine, an important and highest component of betamint, during the starter-grower period from days 1 - 56 of age. The results of the present study also agree with the findings of Hassan et al. [32] that betaine increased body weight gain in growing chicks and improved feed consumption of chicks during the starter-grower period from days 1 - 56 of age. Augustine et al. [33], Waldenstedt et al. [34] and Metzler Zebeli [35] also showed that betaine increased body weight gain and improved feed consumption rate in chicks. Hassan et al. [32] demonstrated that the effect of betaine was apparent in early phase $(1-28$ days $)$ of growth, but declined with advanced age of chicks ( 29 - 52 days). The findings of the authors, thus, demonstrated that betaine exerted its antioxidant effect more markedly during the early phase of growth in pullets. Similarly, Sayed and Dowing [36] reported that the beneficial effect of betaine was apparent in the first few days of administration in broilers exposed to heat stress. The thermal micro-environmental factors may also play a crucial role in modulating the effect of betamint on growth promotion in chicks. Thus, the differences between the findings of the

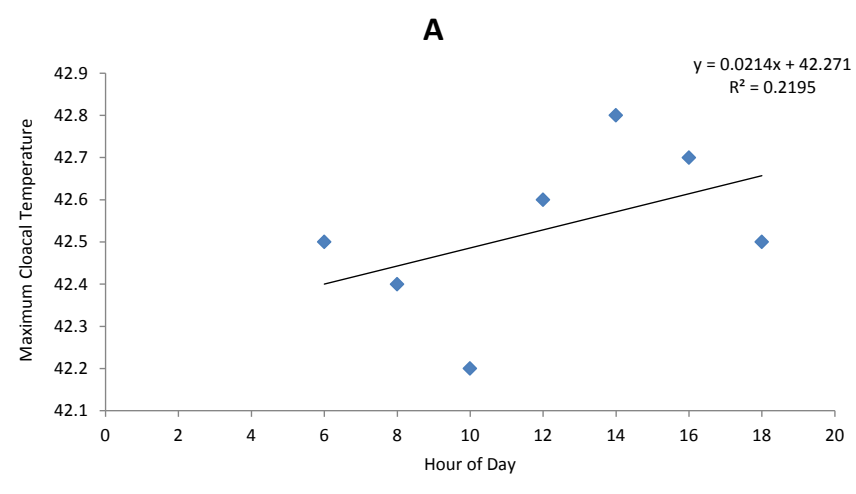

B

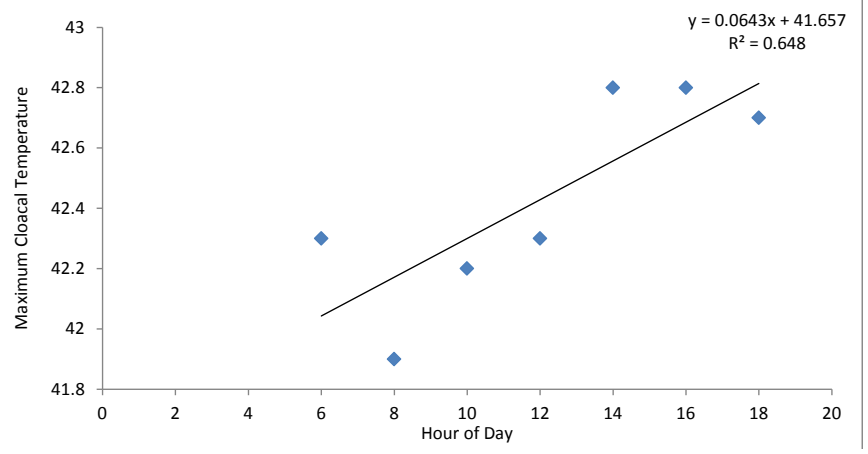

$A=$ Experimental Pullets; $B=$ Control Pullets

Figure 2: Relationship between Maximum Cloacal Temperature $\left({ }^{\circ} \mathrm{C}\right)$ and Hour of Day (h) in Experimental (A) and Control (B) Pullets during the Hot-dry Season. 

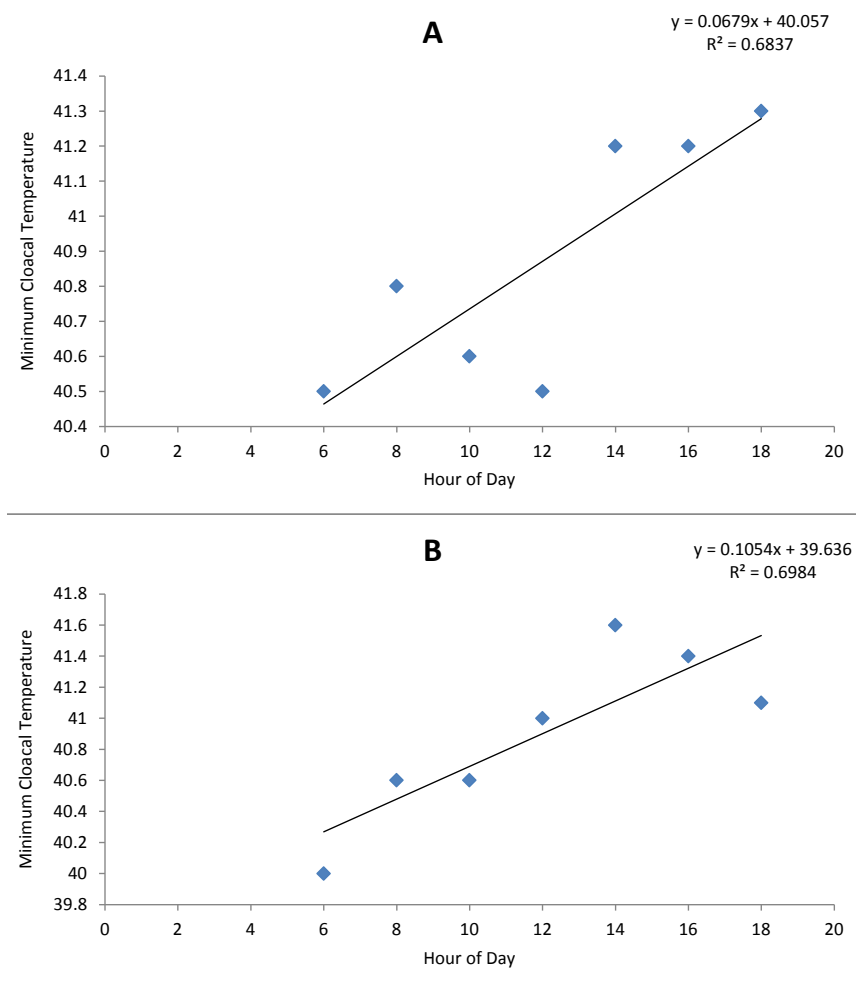

$\mathrm{A}=$ Experimental Pullets; $\mathrm{B}=$ Control Pullets

Figure 3: Relationship between Minimum Cloacal Temperature $\left({ }^{\circ} \mathrm{C}\right)$ and Hour of Day (h) in Experimental (A) and Control (B) Pullets during the Hot-dry Season

present study and those of Hassan et al. [32] may be due to variations in thermal environmental conditions in Egypt and Nigeria under which the two studies were conducted, respectively. This requires further investigation.

Other factors that modulate the effect of betaine on the growth of chicks are choline or methionine contents of experimental diets [37], which were not investigated in the present study. The fact that methyl-group requirement is higher during early growth phase than later growth phase has been demonstrated [38]. Besides, betamint has been shown to possess diverse physiological activities that improve gastro-intestinal environment [35], including its ability to increase chick resistance to diseases [39] by enhancing the immune functions of birds between days $49-63$ of age. The results of the present study obtained from pullets free from coccidiosis and other diseases disagree with the findings of Waldroup and Fritts [40], which did not observe positive benefits, in terms of body weight gain, feed consumption rate or mortality, in broiler chicks fed betaineadded corn-soy bean meal based diet. The differences in the finding of the present study and that obtained by Waldroup and Fritts [40], who administered only betaine, may be due to the fact that betamint contains other nutrients besides betaine. The other nutrients of betamint are vitamin $\mathrm{C}$, established to play a crucial role in stress amelioration in poultry $[17,24,26,41]$, and calcium, sodium, potassium and magnesium ions. Besides, the study of Waldroup and Fritts[40] was conducted on broilers reared under the temperate climatic conditions.

The CT values showed distinct diurnal fluctuations as evidenced by the lowest and highest values recorded at 06:00 $\mathrm{h}$ and
18:00 h, respectively in experimental $\left(41.34 \pm 0.07^{\circ} \mathrm{C}\right.$ and 41.97 $\pm 0.05^{\circ} \mathrm{C}$, respectively) and control $\left(41.25 \pm 0.08^{\circ} \mathrm{C}\right.$ and $41.82 \pm$ $0.06^{\circ} \mathrm{C}$, respectively) $(\mathrm{P}<0.05)$ pullets. The $\mathrm{CT}$ value in $18: 00 \mathrm{~h}$ in experimental pullets was higher $(\mathrm{P}<0.05)$ than that of the control pullets. The diurnal fluctuations observed in the present study agree with the findings of Sinkalu et al. [24,42], who showed that CT values fluctuate with the hours of the day in pullets. Overall, betamint did not significantly reduced the CT values in the experimental pullets when compared with those of the control pullets, but its effect in reducing CT was evidence during the hot hours of the day (at 12:00 $\mathrm{h}$ and 14:00 h). This finding suggests that the effect of betamint is manifested mainly during the hot hours of the day, when the AT values were very high; that is, at $36.33^{\circ} \mathrm{C}-38.00^{\circ} \mathrm{C}$. Therefore, administration of betamint may be of value in ameliorating the adverse effect of heat stress in pullets during the hot-dry season. It is recommended that in cases where birds are to be unavoidably exposed to heat stress during the season, especially in the afternoon hours of the day, a prior administration of betamint in the morning hours may be of value in alleviating heat stress. The fact that overall mean, mean maximum, mean minimum and mean range values of $\mathrm{CT}$ in the experimental and control birds did not differ significantly indicates that betamint did not induce a significant hypothermic effect in the pullets. Although betamint contains vitamin $\mathrm{C}$, demonstrated to possess hypothermic effect in pullets [43], the other active ingredients of betamint (betaine, magnesium, sodium, calcium and chlorine ions) may play some other synergistic roles. This requires further investigation.

The results of the relationships between the DBT, RH, THI, CT,

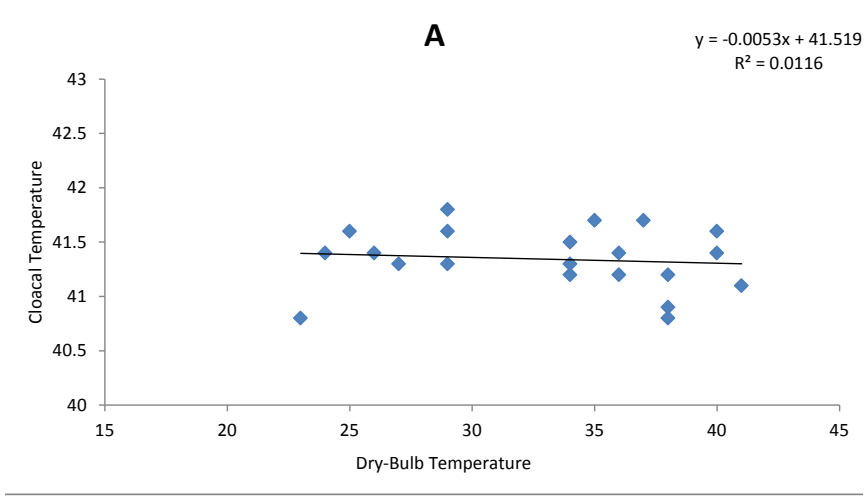

B

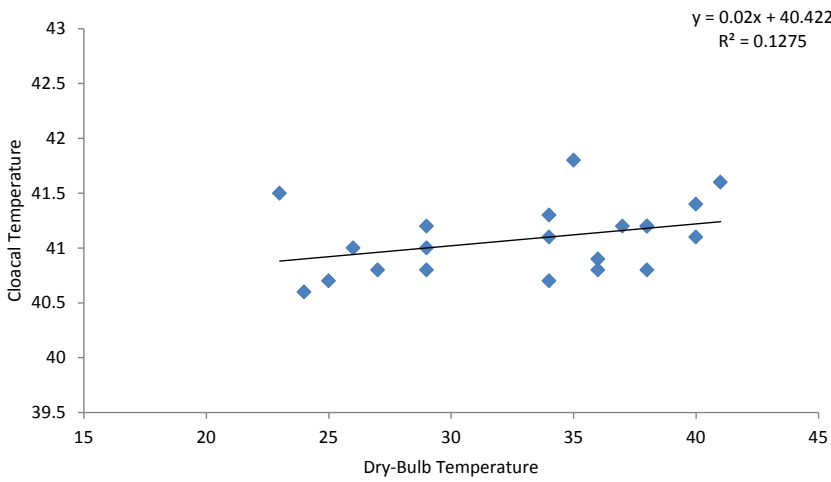

A = Experimental Pullets; $B$ = Control Pullets

Figure 4: Relationship between Cloacal Temperature $\left({ }^{\circ} \mathrm{C}\right)$ and Dry-Bulb Temperature $\left({ }^{\circ} \mathrm{C}\right)$ in Experimental $(\mathrm{A})$ and Control (B) Pullets during the Hot-dry Season. 
A

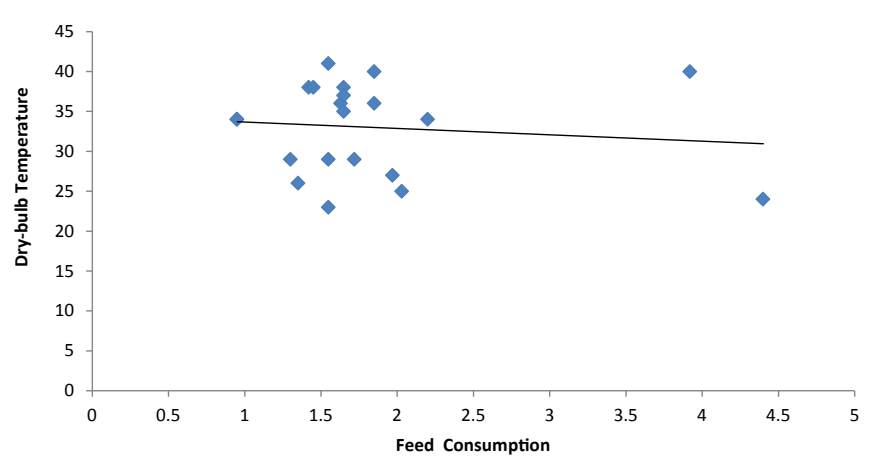

B

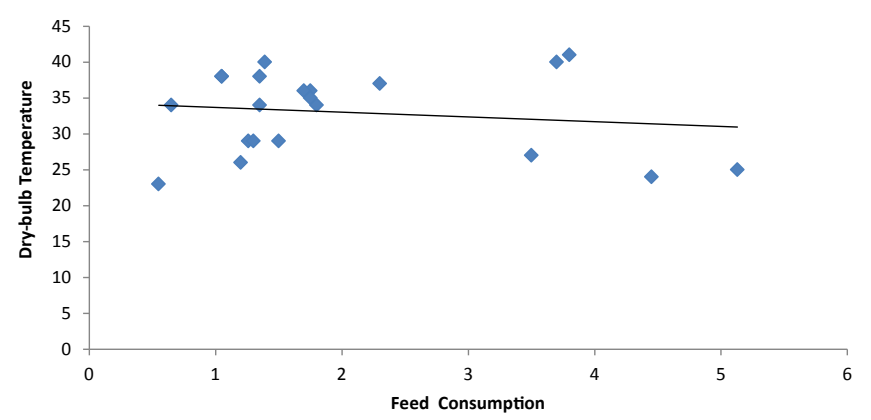

A = Experimental Pullets; $B=$ Control Pullets

Figure 5: Relationship between Dry-bulb Temperature $\left({ }^{\circ} \mathrm{C}\right)$ and Feed Consumption $(\mathrm{kg})$ in Experimental $(\mathrm{A})$ and Control (B) Pullets during the Hotdry Season.

feed consumption and water intake in the present study showed that the relationships were predominantly higher in the experimental than in the control pullets, with the exception of DBT and water intake. This finding is in agreement with the result obtained by Waldenstedt et al. [34], who demonstrated that betamint increased the metabolic rate in birds, resulting in high $\mathrm{CT}$ and feed consumption. However, the fact that a relatively low relationship between DBT and water intake was obtained in experimental pullets compared to control pullets showed that betamint reduced water intake during the hotdry season. This finding agrees with that obtained by Anonymous [21] that betamint increases the adaptation of birds to heat stress; and Mahmoudina and Madani [6], who reported that betaine, the chief component of betamint, initiates the protection of intestinal epithelium against osmotic disturbance. The results of the present study demonstrated that betamint reduced the water intake in birds during heat stress; therefore, its administration may be of tremendous value in raising birds in arid areas, where there is a relative shortage of water, especially during the hot-dry season.

The decrease in relationship between RH and CT, feed and water consumptions recorded in the present study disagreed with the findings of Al-Shkri and Alhassani [44], who demonstrated that water intake in betaine-administered broilers exceeded that obtained in control broilers, administered with betaine. The difference in the results may be due to the fact that betamint contains other components. In the present study, the relationship between $\mathrm{RH}$ and feed consumption that rose significantly in the control pullets, unlike in the experimental pullets, indicates high demand in feed consumption in untreated pullets. This demand may further aggravate the economic losses incurred by the poultry farmers during the hot-dry season. betamint, however, decreased feed consumption with increase in RH. It has been observed by Abu-Dieyeh [45] and Dzenda et al. [46] that high DBT decreases feed consumption, adversely affecting liveweight gain. The finding that betamint increased feed consumption with increase in DBT, resulting in a rise in liveweight, in the present study clearly demonstrated that betaminthas a tendency to increase liveweight gains in pullets reared under high AT conditions.

Based on the findings of the present study, betamint is recommended for use bypoultry farmers as a supplement in reducing adverse effects of heat stress, increasing liveweight gain and reduction in feed consumption; thus, increasing poultry profitability during the hot-dry season. It is also recommended that betamint be administered to birds that are to be unavoidably subjected to adverse effects of heat stress, especially during the hot hours of the day. Based on the findings of this study, betamint may be administered to pullets in order to alleviate the negative effects of heat stress during the hot-dry season. It may also be administered to pullets raised in areas where there is a relative shortage of water, especially during the hot-dry season, and in arid and semi-arid zones.

In conclusion, betamint administration significantly reduced CT values of pullets during the hot hours of the day, at 12:00 h and 14:00 $\mathrm{h}$. Its administration to pullets increased live weightgain, improved feed consumption and reduced water intake during the hot-dry season.

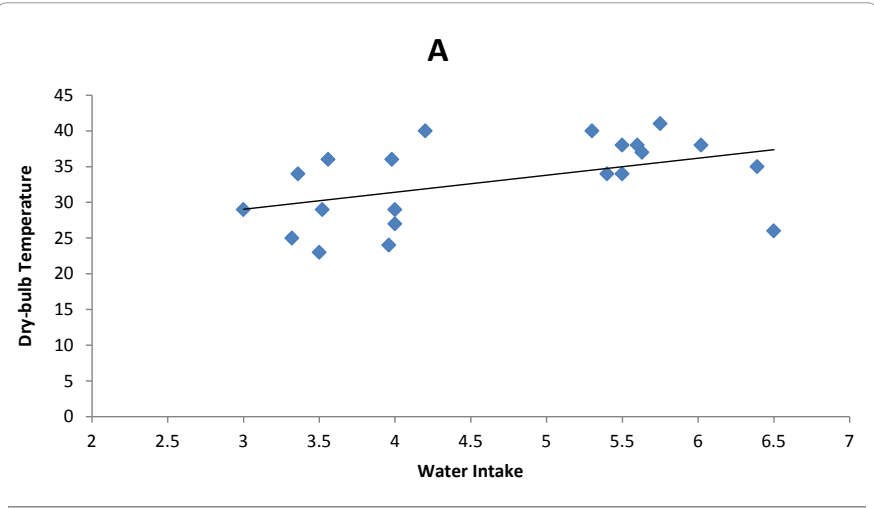

B

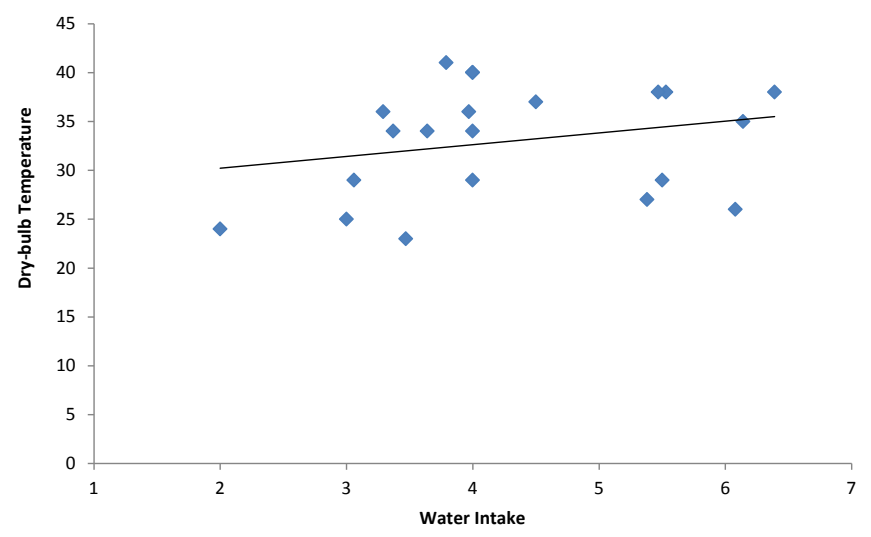

$A=$ Experimental Pullets; $B=$ Control Pullets

Figure 6: Relationship between Dry-bulb Temperature $\left({ }^{\circ} \mathrm{C}\right)$ and Water Intake $(\mathrm{L})$ in Experimental (A) and Control (B) Pullets during the Hot-dry Season. 
Citation: Ayo JO, Danbirini S, Egbuniwe IC, Sinkalu VO (2014) Cloacal Temperature Responses and Some Performance Indices in Black Harco Pullets Administered with Betamint during the Hot-Dry Season. J Veterinar Sci Technol 5: 166. doi:10.4172/2157-7579.1000166
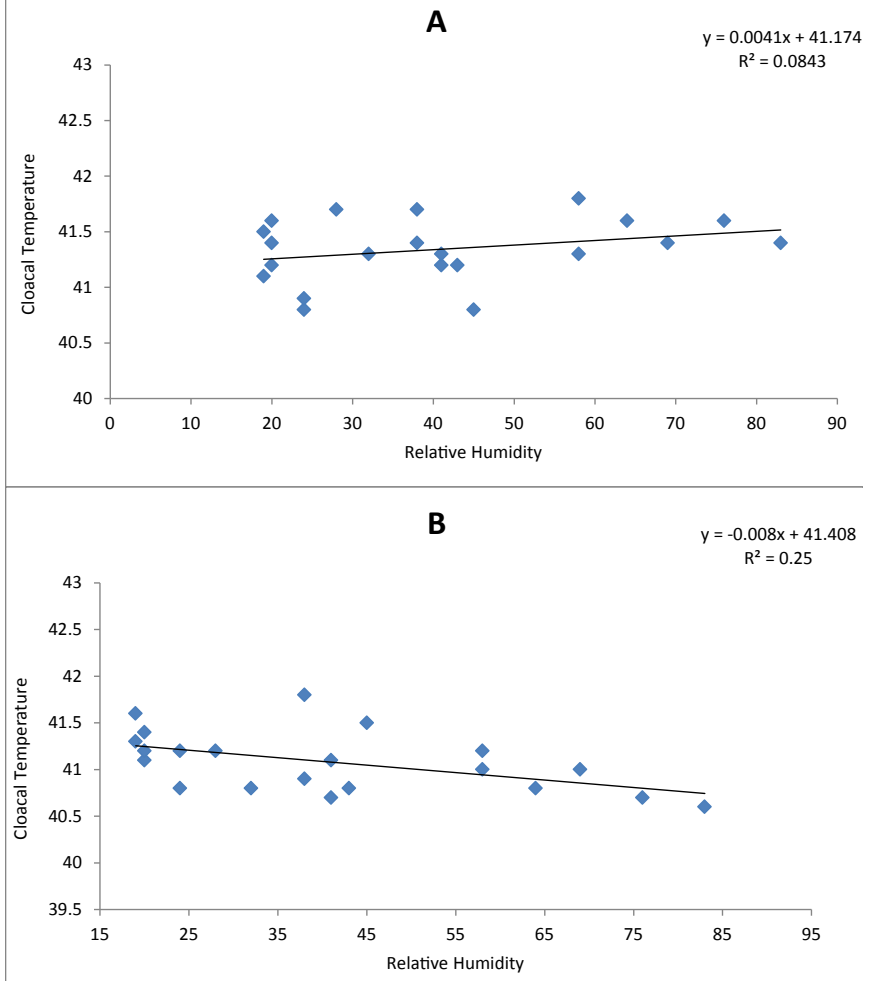

$A=$ Experimental Pullets; $B=$ Control Pullets

Figure 7: Relationship between Cloacal Temperature $\left({ }^{\circ} \mathrm{C}\right)$ and Relative Humidity (\%) in Experimental (A) and Control (B) Pullets during the Hot-dry Season.

\section{References}

1. Anna W, Arango J, Settar P, Fulton JE, Fernando RL, et al. (2014) Genome wide association study for heat stress mortality in a white egg layer line. Plant AnimGenom. International Plant and Animal Genome Conference January 11 - 15, 2014. USA, Pp 641

2. Khattak FM, Acamovic J, Sparks N, Paslia ZN, Joiya MA, et al. (2012) Comparative efficency of different supplementations used to reduce effect of stress in broilers. Pakistan $\mathrm{J}$ Zool 44: 31-41.

3. Rhoads RP, Baumgard LH, Suagee JK (2013) 2011 and 2012 Early Careers Achievement Awards: metabolic priorities during heat stress with an emphasis on skeletal muscle. J AnimSci 91: 2492-2503.

4. Gross WB, Siegel HS (1983) Evaluation of the heterophil/lymphocyte ratio as a measure of stress in chickens. Avian Dis 27: 972-979.

5. Mujahid A (2011) Nutritional strategies to maintain efficency and production of chickens under high enviromental temperature J. PoultSci 48: 145-154.

6. Mahmoudina N, Madani MN (2012) Effects of betaine on performance and carcass composition of broiler chicken in warm weather-a review. Int J AgricSci 2: $675-683$.

7. Melesse A, Maak S, Schmicolt R, von Lengerken G (2011) Effect of longterm heat stress on some performance traits and plasma enzymes activities in naked-necked chicken and their F1 crosses with commercial layer breeds. LivestSci 114: 227-231.

8. Azad KMA, Kikusato M, Azharul M, Hoque AM, Toyomizu M (2010) Effect of chronic heat stress on performance and oxidative damage in different strain of chickens. J PoultSci 47: 333-337.

9. Yunis R, Cahaner A (1999) The effects of the naked neck $(\mathrm{Na})$ and frizzle $(\mathrm{F})$ genes on growth and meat yield of broilers and their interactions with ambient temperatures and potential growth rate. PoultSci 78: 1347-1352.

10. Nardone A, Ronchi B, Lacetera N, Ranieri MS, Bernaducci U (2010) Effects of climate changes on animal production and sustainability of livestock system. LivestSci 130: 57-69.
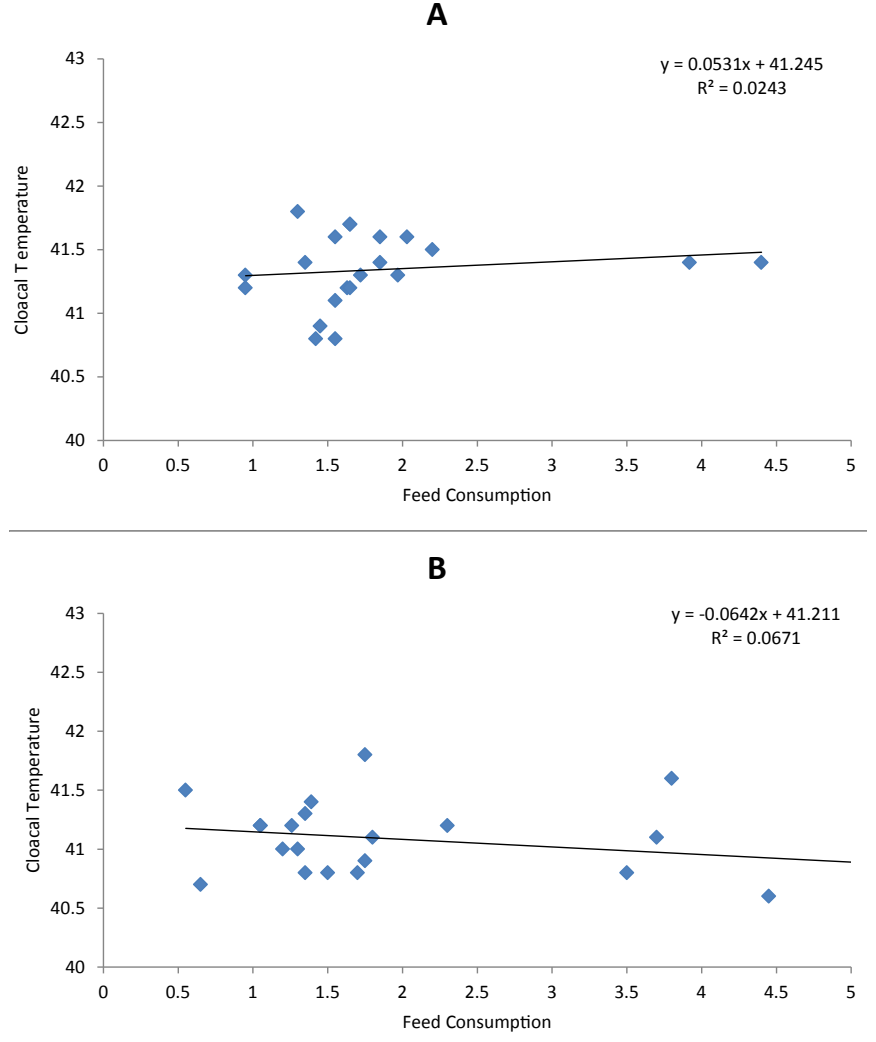

$A=$ Experimental Pullets; $B=$ Control Pullets

Figure 8: Relationship between Cloacal Temperature $\left({ }^{\circ} \mathrm{C}\right)$ and Feed Consumption ( $\mathrm{kg}$ ) in Experimental (A) and Control (B) Pullets during the Hotdry Season.

11. Mujahid A, Sato K, Akiba Y, Toyomizu M (2006) Acute heat stress stimulates mitochondrial superoxide production in broiler skeletal muscle, possibly via downregulation of uncoupling protein content. PoultSci 85: 1259-1265.

12. Salganik RI (2001) The benefits and hazards of antioxidants: controlling apoptosis and other protective mechanisms in cancer patients and the human population. J Am CollNutr 20: 464S-472S.

13. Dröge W (2002) Free radicals in the physiological control of cell function Physiol Rev 82: 47-95.

14. Tan GY, Yang L, Fu YQ, Feng JH, Zhang MH (2010) Effects of different acute high ambient temperatures on function of hepatic mitochondrial respiration, antioxidative enzymes, and oxidative injury in broiler chickens. PoultSci 89: $115-122$.

15. Abidin Z, Khatoo A (2013) Heat stress in poultry and the beneficial effects of ascorbic acid (ascorbic acid) supplementation during periods of heat stress. World's PoultSci J 69: 135-152.

16. Ayo JO, Obidi JA, Rekwot PI (2011) Effects of heat stress on the well-being fertility, and hatchability of chickens in the northern Guinea savannah zone of Nigeria: a review. ISRN Vet Sci 2011: 838606.

17. Minka NS, Ayo JO (2010) Behavioural and rectal temperature responses of Black Harco pullets administered vitamins $C$ and $E$, and transported by road during the hot-dry season. J Vet Behav: Clin App Res 5: 134-144.

18. McKee JS, Harrison PC (2013) Supplemental ascorbic acid does not affect heat loss in broiler chickens exposed to elevated temperature. J ThermBiol 38: $159-162$.

19. McKee SR, Sams AR (1997) The effect of seasonal heat stress on rigo development and the incidence of pale, exudative turkey meat. PoultSci 76: 1616-1620.

20. Alirezaei M, Reza Gheisari H, Reza Ranjbar V, Hajibemani A (2012) Betaine: 
Citation: Ayo JO, Danbirini S, Egbuniwe IC, Sinkalu VO (2014) Cloacal Temperature Responses and Some Performance Indices in Black Harco Pullets Administered with Betamint during the Hot-Dry Season. J Veterinar Sci Technol 5: 166. doi:10.4172/2157-7579.1000166

Page 8 of 8

a promising antioxidant agent for enhancement of broiler meat quality. $\mathrm{Br}$ PoultSci 53: 699-707.

21. Anonymous (2007) Technical Dossier. Invesa International, Spain, Pp:129

22. Ayo JO, Oladele SB, Fayomi A, Jumbo SD, Hambolu JO (1998) Body temperature, respiration and heart rates in the Red Sokoto goat during the harmattan season. Bull Anim Health Prod Afri 46: 161-166.

23. Ayo JO, Oladele SB, Ngam S, Fayomi A, Afolayan SB (1999) Diurnal fluctuations in rectal temperature of the Red Sokoto goat during the harmattan season. Res Vet Sci 66: 7-9.

24. Sinkalu VO, Ayo JO, Adelaiye AB, Hambolu JO (2008) Diurnal fluctuation in rectal temperature of Black Harco pullets administered ascorbic acid during the hot-dry season. Int J Meteorol 33: 327-333.

25. Dzenda T, Ayo JO, Lakpini CAM, Adelaiye AB (2011) Diurnal, seasonal and sex variations in rectal temperature of African Giant rat (Cricetomysgambianus, Waterhouse). J ThermBiol 36: 255-263.

26. Ayo JO, Sinkalu VO (2007) Effects of ascorbic acid on diurnal variations in cloacal temperature of Shaver Brown pullets during the hot-dry season. Int $\mathrm{J}$ PoultSci 6: 612-616.

27. Igono MO, Molokwu EC, Aliu YO (1983) Seasonal variations in rectal temperature of Yankasa sheep. Vet Res Commun 6: 223-226.

28. Ayo JO, Fayomi A, Jumbo SD, Hambolu JO, Oladele SB (1996) Diurnal variation in rectal temperature of Red Sokoto goats during the harmattan season. Paper presented at the Annual Congress of the Nig Vet Med Ass, Enugu-Nigeria.

29. Oke UK (2011) Influence of some major genes on growth traits of local pullets in humid tropical environment. AgricBiol J North America 2: 570-576.

30. Zulovich JM, DeShazer JA (1990) Estimating egg production declines at high environmental temperatures and humidifies. ASAE Paper No. 90-4021. St. Joseph, Michigan:ASAE.

31. Snedecor GW, Cochran WG (1980) Statistical Methods. 7th Ed. Ames: lowa State University Press, USA Pp: 507.

32. Hassan RA, Attai YA, El-Ganzori EH (2005) Growth, carcass quality and seven constituents of slow growing chicks as affected by betaine $₫$ addition to diets containing different levels of choline. Int J PoultSci 4: 840-850.

33. Augustine PC, McNaughton JL, Virtanen E, Rosi L (1997) Effect of betaine on the growth performance of chicks inoculated with mixed cultures of avian Eimeria species and on invasion and development of Eimeriatenella and Eimeriaacervulina in vitro and in vivo. PoultSci 76: 802-809.
34. Waldenstedt L, Elwinger K, Thebo P, Uggla A (1999) Effect of betaine supplement on broiler performance during an experimental coccidial infection. PoultSci 78: 182-189.

35. Metzler-Zebeli BU, Eklund MR, Mosenthin R (2009) Impact of osmoregulation and methyl-donor functions of betaine on intestinal health and performance in poultry. World's PoultSci J 65: 419-442.

36. Sayed MA, Downing J (2011) The effects of water replacement by ora rehydration fluids with or without betaine supplementation on performance, acid-base balance, and water retention of heat-stressed broiler chickens. PoultSci 90: 157-167.

37. Dilger RN, Garrow TA, Baker DH (2007) Betaine can partially spare choline in chicks but only when added to diets containing a minimal level of choline. $J$ Nutr 137: 2224-2228.

38. Wang YZ, Xu ZR, Feng G (2004) The effects of betaine and DL-methionine on growth performances and carcass characteristics in meat ducks. Anim Feed SciTechnol 116: 151-159.

39. Remus JC, Pierson EEM, Hruby M (2004) The evaluation of betaine and enzymes in coccidian-challenged broilers. 22nd Poultry Congress, Turkey, 8-13th June, Pp: 29.

40. Waldroup DW, Fritts CA (2005) Evaluataion of separate and combined effects of choline and betaine in diets of male broilers. Int J PoultSci 4: 442-448.

41. Minka NS, Ayo JO (2008) Haematology and behaviour of pullets transported by road and administered with ascorbic acid during the hot-dry season. Res Vet Sci 85: 389-393.

42. Sinkalu VO, Ayo JO, Adelaiye AB, Hambolu JO (2008a) Effects of vitamin E on diurnal variation in rectal temperature of Black Harco pullets during the hot-dry season. J ThermBiol 33: 32-66.

43. Ayo JO, Owoyele OO, Dzenda T (2007) Effects of ascorbic acid on diurna variations in rectal temperature of BovanNera pullets during the harmattan season. International J PoultSci 6: 612-616.

44. Al-Shkri A, Alhassan D (2012) Effect of betaine supplemented in drinking water on water intake pattern of broiler chicken exposed to heat stress. J Turkish UniAgric 2: 1646-1813.

45. Abu-Dieyeh ZM (2006) Effect of high temperature per se on growth performance of broilers. Int J PoultSci 5: 19-21.

46. Dzenda T, Ayo JO, Lakpini CAM, Adelaiye AB (2011) Diurnal, seasonal and sex variations in rectal temperature of African Giant rat (Cricetomysgambianus, Waterhouse). J ThermBiol 36(5): 255-263. 